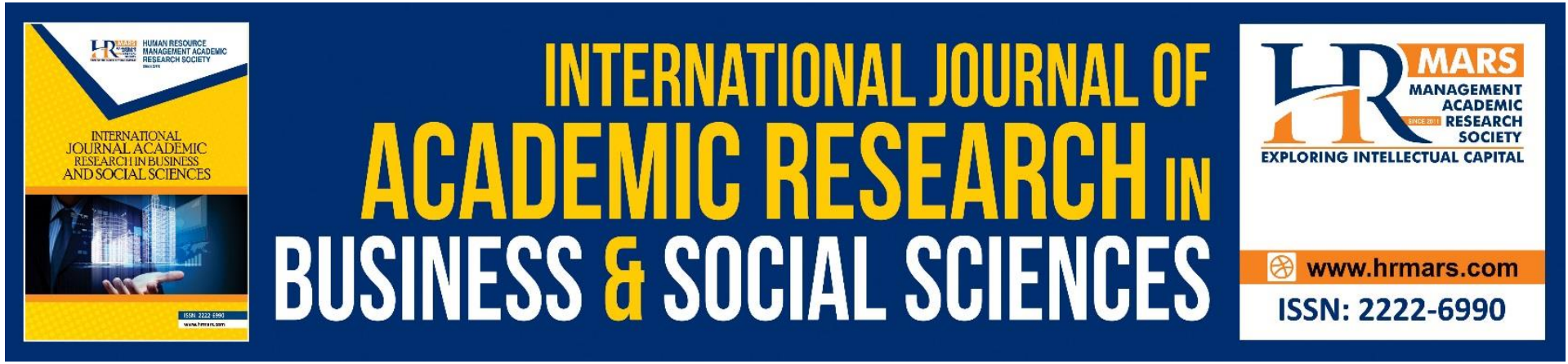

\title{
The Use of Impoliteness Strategies in Online Feedback Relating to A General Election in Media
}

\author{
Lydia Colaco, Angeline Ranjethamoney Vijayarajoo, Teoh Mei Lin
}

To Link this Article: http://dx.doi.org/10.6007/IJARBSS/v11-i9/10975

DOI:10.6007/IJARBSS/v11-i9/10975

Received: 08 July 2021, Revised: 28 July 2021, Accepted: 21 August 2021

Published Online: 10 September 2021

In-Text Citation: (Colaco et al., 2021)

To Cite this Article: Colaco, L., Vijayarajoo, A. R., \& Lin, T. M. (2021). The Use of Impoliteness Strategies in Online Feedback Relating to A General Election in Media. International Journal of Academic Research in Business and Social Sciences, 11(9), 107-121.

Copyright: (c) 2021 The Author(s)

Published by Human Resource Management Academic Research Society (www.hrmars.com)

This article is published under the Creative Commons Attribution (CC BY 4.0) license. Anyone may reproduce, distribute, translate and create derivative works of this article (for both commercial and non-commercial purposes), subject to full attribution to the original publication and authors. The full terms of this license may be seen at: http://creativecommons.org/licences/by/4.0/legalcode

Vol. 11, No. 9, 2021, Pg. 107 - 121

http://hrmars.com/index.php/pages/detail/IJARBSS

JOURNAL HOMEPAGE

Full Terms \& Conditions of access and use can be found at http://hrmars.com/index.php/pages/detail/publication-ethics 


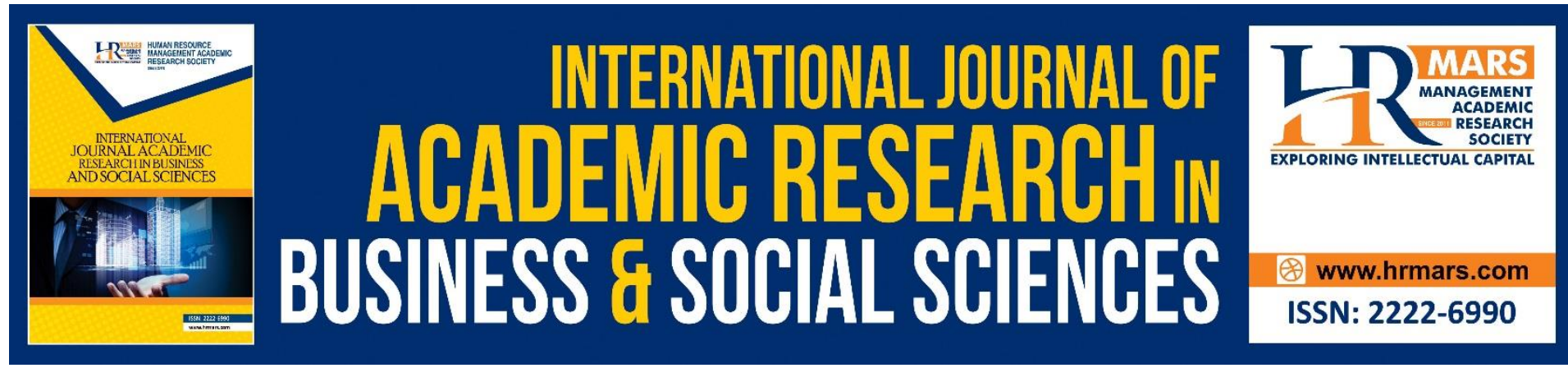

\title{
The Use of Impoliteness Strategies in Online FeedbackRelating to A General Election in Media
}

\section{Lydia Colaco ${ }^{1}$, Angeline Ranjethamoney Vijayarajoo², Teoh Mei $\operatorname{Lin}^{3}$}

${ }^{1}$ S.M.K Ghafar Baba, 78300 Masjid Tanah, Melaka, Malaysia, ${ }^{2}$ Academy of Language Studies, Universiti Teknologi Mara, Negeri, Sembilan, Malaysia

Email: lydia.colaco@gmail.com, angierv@uitm.edu.my

\begin{abstract}
The spike in Computer Mediated Communication (CMC) has overspilled into online political discussions enabling the free expression of political views in various platforms. This study aims at investigating the frequency of impolite strategies used by netizens in their political discussions online. The study also aims at finding out the reasons for employing such impoliteness strategies by netizens. In order to answer these questions, a total of 150 impolite feedback responses of netizens were collected from the online news portal Malaysiakini. The feedback responses formed the backbone of the data for the study. This data were analysed based on the model of impoliteness by Culpeper $(1996,2005)$ in the field of pragmatics. The findings revealed that impolite strategies were present. The interview data further revealed that the main reasons contributing to the use of impoliteness was anger, more precisely, pent-up anger.
\end{abstract}

Keywords: Netizens, Impoliteness Strategies, CMC, Face Threatening Act (FTA)

\section{Introduction}

Elections are often the time when emotions are at their peak. Voters feel a sense of vulnerability causing uncertainty and easily triggered emotional anxiety. This scenario is no different in Malaysia. Thespike in Computer Mediated Communication (CMC) in recent years however, has enabled Malaysiansto channel these politically driven emotions online. The present research looks into these expressions in the feedback comment section in online news pertaining to a general election in the country.

\section{Problem Statement}

The online platform has become a convenient and seemingly safe place to express oneself for various reasons which will be stated in the Literature Review. This provides avenues not only for shared values but also conflicts (Vladimirou \& House, 2018). Past studies commonly looked at impoliteness strategies in the spoken genre. In recent years, however, research in the digital genre has begun to gain momentum. Nonetheless, research on impoliteness in the digital medium is by far scarce considering the abundance of data generated daily. 
Some work on impoliteness has been done in social networking sites (Atyaf Hasan, 2020; Fairus Azzaya, 2018; Nurul Akmal, 2018; Oz, Pei, \& Gina, 2017; Shamilah, 2015) ; however comments on these sites are known to be more civil. Researchers have since found fertile ground for stark impoliteness in online news sites giving rise to numerous researches on impoliteness around the globe (Rabab'ah, 2019; Mahrani, 2017; Xiangdong, 2017). Studies, however, have yet to look at impoliteness strategies in online news in a local context. This study aims at filling this gap by studying impoliteness during a national event as large as a national election.

\section{Research Questions}

In order to gather an in-depth understanding on impoliteness expressed through the internet, this study aims at answering the following research questions:

1. How frequently are the various impoliteness strategies employed by netizens in their political discussions online?

2. What are the reasons netizens resort to employing these impoliteness strategies?

\section{Literature Review Impoliteness}

Early literature on impoliteness saw Goffman (1967) with the notion of aggressive face work which was later supported by Watts (2003). Culpeper's revised version in 2005 introduced two ways of communicating impoliteness. First, this is seen when face threat is communicated intentionally; second, when the constructed behaviour is perceived as intentionally face-attacking.

Despite varying definitions, two glaring shared commonalities were the notion of faceand intent. Hu (1944) traced the notion of face in Chinese history to the modern term mianzi roughly translated as 'prestige', 'reputation', 'face'. The notion of face was also spotted in Culpeper (2011) and Goffman (1967) who described face as involving notions such as prestige, self-esteem and reputation. A different view of impoliteness was seen in subsequent researches (Hammod \& Abdul-Rassul, 2017; Spencer-Oatey, 2005; Watts, 2003) suggesting the act of impoliteness as resulting in social disruption.

Extensive research has been conducted in the field of politeness neglecting impoliteness altogether (Leech, 2007), as Locher and Bousfield (2008, p. 2) calls it the "poor cousin of politeness". Realising the lack of research in the opposing orientation, Culpeper (1996) conducted a study analysing impoliteness that occurs in an army recruit training programme and in the discourse of drama, in an attempt to build a framework parallel and opposite to Brown and Levinson's (1987). This Theory of Impoliteness will be adopted in the present research and explained.

\section{Culpeper's Model of Impoliteness}

In more recent work Culpeper (2011) introduced four strategies in analysing impoliteness namely; insults, personalised negative assertions, personalised negative references and personalised third-person negative references. This formula however was not adopted in this study as the over emphasis on lexical items would limit the scope of the present study. Therefore, the present study employs the Culpeper $(1996,2005)$ impoliteness model to understand the strategies used by Malaysians in giving online comments to their politicians. In this study, Culpeper's $(1996,2005)$ notion of impoliteness is applied as it is considered 
most fitting given that this research is concerned with how impoliteness is intentionally used by netizens.Culpeper's (1996, 2005) models of impoliteness are provided in Table 1.

Table 1: Models of Impoliteness

\begin{tabular}{|c|c|}
\hline Impoliteness Strategies & Definition \\
\hline Bald on-record impoliteness & $\begin{array}{l}\text {-the Face Threatening Act is executed clearly, directly, } \\
\text { in a concise and unmistakable manner in situations } \\
\text { where the face is not diminished. }\end{array}$ \\
\hline Positive impoliteness & $\begin{array}{l}\text {-strategies used to damage the addressee's positive } \\
\text { facewants. }\end{array}$ \\
\hline Ignore, snub the other & -fail to acknowledge the other's presence. \\
\hline $\begin{array}{l}\text { Exclude the other from an } \\
\text { activity }\end{array}$ & \\
\hline Disassociate from the other & $\begin{array}{l}\text {-deny association or common ground with the } \\
\text { other;avoid sitting together. }\end{array}$ \\
\hline $\begin{array}{l}\text { Be disinterested, } \\
\text { unconcerned,unsympathetic }\end{array}$ & \\
\hline $\begin{array}{l}\text { Use inappropriate } \\
\text { identitymarkers }\end{array}$ & $\begin{array}{l}\text {-use title and surname when a close relationship } \\
\text { pertains, or a nickname when a distant relationship } \\
\text { pertains. }\end{array}$ \\
\hline $\begin{array}{l}\text { Use obscure or secretive } \\
\text { language }\end{array}$ & $\begin{array}{l}\text {-for example, mystify the other with jargon, or use a } \\
\text { code known to others in the group, but not the } \\
\text { target. }\end{array}$ \\
\hline Seek disagreement & -select a sensitive topic \\
\hline $\begin{array}{l}\text { Make the other } \\
\text { feeluncomfortable }\end{array}$ & -do not avoid silence, joke, or use small talk. \\
\hline Use taboo words & -swear, or use abusive or profane language. \\
\hline Call the other names & -use derogatory nominations. \\
\hline Negative impoliteness & $\begin{array}{l}\text {-strategies used to damage the addressee's negative } \\
\text { facewants }\end{array}$ \\
\hline Frighten & $\begin{array}{l}\text {-instil a belief that action detrimental to the other will } \\
\text { occur. }\end{array}$ \\
\hline Condescend, scorn or ridicule & $\begin{array}{l}\text {-being patronising, emphasise your relative power } \\
\text { upon others. Be contemptuous. Do not treat the } \\
\text { other seriously. Belittle the other (e.g. use } \\
\text { diminutives). }\end{array}$ \\
\hline Invade the other's space & $\begin{array}{l}\text {-literally (e.g. position yourself closer to the other than } \\
\text { the relationship permits) or metaphorically (e.g. ask for } \\
\text { or speak about information which is too intimate given } \\
\text { the relationship). }\end{array}$ \\
\hline $\begin{array}{l}\text { Explicitly associate the other } \\
\text { with a negative aspect }\end{array}$ & -personalise, use the pronouns ' $I$ ' and 'you'. \\
\hline $\begin{array}{l}\text { Put the other's indebtedness } \\
\text { onrecord }\end{array}$ & \\
\hline
\end{tabular}




\begin{tabular}{|l|l|}
\hline Sarcasm or mock politeness & $\begin{array}{l}\text {-the Face Threatening Act is committed using politeness } \\
\text { strategies that are clearly not sincere. }\end{array}$ \\
\hline Withhold politeness & $\begin{array}{l}\text {-the non-existence of politeness work where it is } \\
\text { expected }\end{array}$ \\
\hline Off-record impoliteness & $\begin{array}{l}\text {-the Face Threatening act is performed in a way there is } \\
\text { more than one indefinite attributable intention } \\
\text { wherebythe actor is not held responsible of committing } \\
\text { it in otherwords, the Face Threatening Act is performed } \\
\text { through an implicature. }\end{array}$ \\
\hline
\end{tabular}

Source (Culpeper, 1996, 2005)

The definitions as provided in the Table 2.1 will be used to analyse the data collected in the study. These definitions would help in distinguishing the fine lines between the different strategies.

\section{Computer Mediated Communication}

Computer mediated communication (hereafter referred to as $\mathrm{CMC}$ ) is a significant field of study. The creativity brought about by coping with the challenges of technology or exploiting $\mathbf{t t}$ has brought about significant innovation in language use. Communicating online has proven to be as real as communicating in real life situations (Locher, 2010). Therefore, it is not surprising that numerous studies have been carried out in the CMC platform.

Lorenzo-Dus, Garcés-Conejos Blitvich and Bou-Franch (2011) conducted a study on impoliteness on YouTube postings in a polylogal setting online where more than two participants were involved. The study aimed at proving that genre could provide both a top down and a bottom-up analysis of impoliteness. Some 13000 words of data were collected from the video named "Obama Reggaeton". Both qualitative and quantitative methods were used to analyse the realisation and interpretation of impoliteness. The findings suggested further refinement of impoliteness taxonomies to aid further examination on how impoliteness is manifested. Further, Shamilah (2015) investigated the type of impoliteness strategies used and the reasons behind them contributing to impoliteness on a politician's Facebook. The study employed the Culpeper (2011) impoliteness strategy to analyse 151 comments in the politician's Facebook. The study concluded that the bald onrecord was the most common strategy employed. The study also offered other important insights stating anonymity, emotion and lack of non-verbal cues are the factors contributing to impoliteness. In line with that, Azahar and Mohd Azizuddin (2016) conducted a content analysis on online news portals during GE13. Kasim and Mohd Sani compared the news published by the mainstream, the alternative and the independent news portals. They concluded that all four mainstream newsportals favoured the Barisan Nasional, the three alternative news portals had completely opposing views while the coverage by the independent news portals namely The Malaysian Insider and Malaysiakini seemed balanced.

According to Azahar and Mohd Azizuddin (2016), Barisan Nasional suffered a declining number of parliamentary seats since GE12 in 2008 with a simple majority of 142 seats out of the 222 which further dropped to 133 seats in GE13. The reasons stated by the Prime Ministerbeing the failure to handle public negative perception online. He added that perceptions can beformed in many ways specifying news portals and social networks. GE14 
as explored in the current study however created history when Barisan Nasional was defeated when they only won 79 seats compared to 113 seats won by the new Pakatan Harapan Government.

Xavierine (2017) explored impoliteness strategies and language use in discussing the Low Yat Plaza incident by YouTube interlocutors. A total of 123 comments were collected from two YouTube videos with the greatest number of impolite comments. The Culpeper (2011) impoliteness framework was employed in data analysis. The study revealed 'insult' as the most common impolite strategy naming profanities as the most common linguistic device in causing face damage. The study also revealed new categories of insult.

Vladimirou and House (2018) in their study examined 1000 tweets on the Greek PrimeMinister Alexis Tsipras interview with the former president of the United States, Bill Clinton.The purpose of the research was to understand how textual, multimodal or moving images werecarefully rearranged in tweets to tap on the cultural aspect of the local community enabling playful crafting of the interview to create mockery of the public figure when it was widely circulated. The research examined ways in which the face attack was brought about and how itcreates entertainment and bonding.

A significant number of researches have been conducted on impoliteness in CMC. However, the purpose of each study varies as the notion of impoliteness is so wide and each study is only capable of covering a tiny aspect of impoliteness. This study looked into the impoliteness strategies employed toward a specific public figure and provides explicit answersto the questions outlined in this study with hopes to contribute to the literature on impolitenesswithin a political setting.

\section{Methodology}

This section describes the qualitative method employed in this study to investigate the impoliteness strategies employed in online feedback.

\section{Theoretical Framework}

This table (Table 2) is a mere overview of Culpeper's Impoliteness Model that was used to analyse thedata in this research. 
Table 2: Model of Impoliteness

\begin{tabular}{|l|}
\hline \multicolumn{1}{|c|}{ Impoliteness Strategies } \\
\hline Bald on-record impoliteness \\
\hline Positive impoliteness \\
\hline Ignore, snub the other \\
\hline Exclude the other from an activity \\
\hline Disassociate from the other \\
\hline Be disinterested, unconcerned, unsympathetic \\
\hline Use inappropriate identity markers \\
\hline Use obscure or secretive language \\
\hline Seek disagreement \\
\hline Make the other feel uncomfortable \\
\hline Use taboo words \\
\hline Call the other names \\
\hline Negative impoliteness \\
\hline Frighten \\
\hline Condescend, scorn or ridicule \\
\hline Invade the other's space \\
\hline Explicitly associate the other with a negative aspect \\
\hline Put the other's indebtedness on record \\
\hline Sarcasm or mock politeness \\
\hline Withhold politeness \\
\hline Off-record impoliteness \\
\hline
\end{tabular}

Source (Culpeper, 1996, 2005)

Culpeper's model of impoliteness consists of six strategies namely; bald on-record impoliteness, positive impoliteness, negative impoliteness, sarcasm, withhold politeness and off-record impoliteness. These strategies were used as an analytical tool in the present study.

\section{Research Site}

The homogeneous method of data collection was employed in collecting the required data in this study. According to Creswell (2014), a particular site based on traits and characteristic can be purposefully selected. Therefore, the data in this study were collected from the Malaysiakinionline news reporting website as it is famous among those seeking a neutral perspective on news. The website was specially chosen because of its popularity as an independent media andi vigilance to the influence of finance and power. The samples of feedback that werecollected as data for the present study were taken from the feedback section of the Malaysiakininews report within the month of election that was from the $9^{\text {th }}$ of May 2018 to the $31^{\text {st }}$ of May2018. Online interview sessions were then held through the google meet platform.

\section{Data Collection Procedure}

In order to control the scope and obtain relevant data for this study, the news reports in Malaysiakini between $9^{\text {th }}$ and $31^{\text {st }}$ May 2018 were analysed. Three headlines starting with (Najib: ...) were chosen. 
Out of the substantial data obtained, only the first 50 comments in English from each news report that did not exceed the word limit of 30 words were chosen for analysis. The 150 comments selected were then saved for analysis.

In order to understand the reasons behind the comments, 10 working class adults were interviewed through the google meet platform. The interview was recorded and transcribed forfurther analysis.

\section{Data Analysis}

In order to analyse the data, the Culpeper $(1996,2005)$ Impoliteness Model was employed. First,the comments from the website were copied to Microsoft Word in order to obtain a printable copy.

The data were then analysed according to Culpeper's $(1996,2005)$ model of impoliteness in order to identify the strategies of impoliteness and the language legalisation inthe feedback. The types of strategies employed in the data will be used to answer Research Question 1. The interview transcripts were analysed and patterns arising will be used to answer Research Question 2.

\section{Analysis and Discussion}

This section presents the findings for this study based on Culpeper's $(1996,2005)$ theoretical framework. The theoretical framework of Culpeper's model of impoliteness is used to explore impoliteness strategies used in the online feedback of the Malaysiakini online news portal.

\section{Findings}

The findings reveal the frequencies of impoliteness strategies employed in Malaysiakini's online feedback over the duration stipulated. Table 3 shows the frequencies of impoliteness strategies. 
Table3: Frequencies of Impoliteness Strategies

\begin{tabular}{|c|c|c|c|c|c|c|}
\hline \multirow[t]{2}{*}{ Strategies } & \multicolumn{6}{|c|}{\begin{tabular}{|l|l|l|l|l|l|l|} 
H 1 & H 2 & H 3 & Total Percentage Overall \\
\end{tabular}} \\
\hline & (No) & $($ No) & (No) & & $(\%)$ & Percentage \\
\hline on-recordimpoliteness & 15 & 6 & 8 & 29 & 8.58 & 8.58 \\
\hline Positive Impoliteness & & & & & & 41.12 \\
\hline 1. Ignore, snub theother & 5 & 2 & 2 & 9 & 2.66 & \\
\hline 2. Exclude theother from an activity & 1 & 3 & 1 & 5 & 1.48 & \\
\hline 3. Disassociate from the other & 1 & 3 & 1 & 5 & 1.48 & \\
\hline 4. Be disinterested, unconcerned, unsympathetic & 13 & 10 & 10 & 33 & 9.76 & \\
\hline 5. Use inappropriate identity markers & 4 & 2 & 2 & 8 & 2.37 & \\
\hline 6. Use obscure or secretive language & 0 & 0 & 0 & 0 & 0 & \\
\hline 7. Seek disagreement & 15 & 8 & 8 & 31 & 9.17 & \\
\hline 8. Make the other feel uncomfortable & 12 & 9 & 13 & 34 & 10.06 & \\
\hline 9. Use taboo words & 1 & 1 & 2 & 4 & 1.18 & \\
\hline 10 Call the other names & 2 & 4 & 4 & 10 & 2.96 & \\
\hline Negative Impoliteness & & & & & & 37.87 \\
\hline 1. Frighten & 3 & 1 & 2 & 6 & 1.78 & \\
\hline 2. Condescend & 4 & 3 & 10 & 17 & 5.03 & \\
\hline 3. Invade theother's space & 0 & 1 & 1 & 2 & 0.59 & \\
\hline $\begin{array}{l}\text { 4. Explicitly associate the otherwith a negative } \\
\text { aspect }\end{array}$ & 643 & 32 & 28 & 103 & 30.47 & \\
\hline 5. Put the other's indebtedness on record & 0 & 0 & 0 & 0 & 0 & \\
\hline Sarcasm & 9 & 12 & 7 & 28 & 8.28 & 8.28 \\
\hline Withhold politeness & 0 & 0 & 0 & 0 & 0 & 0 \\
\hline Off record impoliteness & 4 & 5 & 5 & 14 & 4.14 & 4.14 \\
\hline Total & 132 & 102 & 104 & 338 & 100 & 100 \\
\hline
\end{tabular}

Table 3 shows the number of occurrences of each of the impoliteness strategies underthe three news headlines. The table also gives the number of times each strategy was used in the data and answers Research Question 1. In total, there were 338 instances of impoliteness strategies employed. Out of these, the positive impoliteness strategy provedto be the most prevalent strategy making up $41.12 \%(n=139)$ of the total strategies, followed by the negative impoliteness strategy making up $37.8 \%(n=128)$, bald on-record impoliteness and sarcasm/mock politeness revealed close percentages of $8.5 \%(n=29)$ and $8.28 \%(n=28)$ respectively. Off-record impoliteness strategy made up $4.14 \%(n=14)$ of the total data, while no instances of withhold politeness was found in the data. 
The present study found that the positive impoliteness strategy was the most frequently employed among all the strategies used. Under this strategy, the number of occurrences of making the other feel uncomfortable, being disinterested, unconcerned and unsympathetic, as well as seeking disagreement were more significant.

\begin{tabular}{|c|c|c|c|}
\hline Headline & Feedback & Example & Strategies of impoliteness \\
\hline $\mathrm{H} 2$ & F14 & $\begin{array}{l}\text { If the photographer took a picture o } \\
\text { the crowd we may see most of the } \\
\text { women in Pekan clutching Birkin } \\
\text { handbags. }\end{array}$ & $\begin{array}{l}\text { making the other fee } \\
\text { uncomfortable }\end{array}$ \\
\hline $\mathrm{H} 1$ & $\mathrm{~F} 4$ & $\begin{array}{l}\text { This man is beyond redemption. } \\
\text { think even if God spoke to you, you } \\
\text { wouldn't listen. }\end{array}$ & \begin{tabular}{|lr} 
being & disinterested \\
unconcerned & anc \\
unsympathetic &
\end{tabular} \\
\hline $\mathrm{H3}$ & F24 & $\begin{array}{l}40 \text { points or } 2.2 \% \text { drop is smal } \\
\text { matter....caused by a } 3 \text { or } 4 \text { composite } \\
\text { index counters declined such as } \\
\text { Axiata and your brother's } \\
\text { counter.... CIMB. }\end{array}$ & seeking disagreement \\
\hline
\end{tabular}

As can be seen from the given examples, the three most preferred strategies employedwere strategies where impoliteness was less direct. Negative impoliteness takes the secondplace as the most preferred impoliteness strategy. Under this strategy, it was found that explicitly associating the other with a negative aspect made up the bulk of the data.

\begin{tabular}{|l|l|l|l|}
\hline Headline & Feedback & Example & Strategies of impoliteness \\
\hline H1 & F31 & $\begin{array}{l}\text { Sounds Trumpian, no, how he blamesExplicitly associate the othen } \\
\text { everyone else but himself and thewith a negative aspect } \\
\text { shopoholic (sic) wife! }\end{array}$ \\
\hline
\end{tabular}

As shown in the example, the politician is associated with the negative character of Trump. Similar examples of associating the politician with a negative aspect were seen throughout the data as it tends to overlap with other strategies

In answering Research Question 2 the analysis of the interviews provided perspectiveson the reasons for netizens resorting to impoliteness. The following Table 4 gives the perspectives identified from the feedback obtained. 
Table 4: Reasons for Resorting to Impoliteness

\begin{tabular}{|c|c|}
\hline Reason & Example \\
\hline Fear & $\begin{array}{l}\text { Let him be corrupted that he's making money or whatever. As long as } \\
\text { he's, not picking on my rice bowl. So what The Politician did was to pick } \\
\text { on everybody's rice bowl. That's when people got angry. People go } \\
\text { frustrated, because he raised the prices, he increased the taxes and he } \\
\text { did all that kind of nonsense to cover up the cost. }\end{array}$ \\
\hline Disagreement & none of them have agreed to what the politician have said. \\
\hline \multicolumn{2}{|c|}{$\begin{array}{l}\begin{array}{l}\text { Anger, Fury (Blamingokay, so that is people are angry with him already lar. So, People, } \\
\text { others, refuse tcmean, people are fed up and people are angry with him. So, they are } \\
\text { accept blame) } \\
\text { showing their frustration through that they are write-ups. } \\
\text {..they were furious with The Politician's statement as he was, he was } \\
\text { blaming it on the system and they they felt that he should take the } \\
\text { blame on himself. }\end{array}\end{array}$} \\
\hline Pent up Anger & $\begin{array}{l}\text { He says it's a built-up frustration and they are just showing it on this } \\
\text { particular article. it's not referring to only one this particular article. }\end{array}$ \\
\hline sty & $\begin{array}{l}\text { the whole world is talking about it and you are just hiding Under the } \\
\text { carpet. And you think people are so much fool. So all these frustrations } \\
\text { have built up. That's why they came up with all these comments. }\end{array}$ \\
\hline Frustration & $\begin{array}{l}\text { On the whole. I don't think anybody believes. and the reason that they } \\
\text { have come up with all these comments is because they are reallyangry } \\
\text { that ex- prime minister has taken swindled up all their moneyand } \\
\text { they're not happy with it. And they're just they're just blurting out al } \\
\text { their anger and all their comments in these chat boxes boxes to... to } \\
\text { show their frustration. }\end{array}$ \\
\hline $\begin{array}{l}\text { Let- down, } \\
\text { Disappointment }\end{array}$ & $\begin{array}{l}\text { they were they were disappointed with The Politician's way of } \\
\text { managed management and they were they were disappointed with } \\
\text { The Politician's way of managed management and they were happy } \\
\text { that the in the election he lost he lost in the election }\end{array}$ \\
\hline Loss of trust/Cheated & $\begin{array}{l}\text { And they are not trusting The Politician anymore. I mean through thei } \\
\text { comments, we can see that. There's no trust at all upon The Politician } \\
\text {...they just don't believe him. }\end{array}$ \\
\hline Shocking disbelief & $\begin{array}{l}\text { see firstly I think they feel disappointed with the our ex-government } \\
\text { Which governed by BN. and there's leftover so much debt, and alsd } \\
\text { they feel shock, you know, when, when they when they announce, } \\
\text { That the government had so much debt. }\end{array}$ \\
\hline Emotional / Irrational & $\begin{array}{l}\text { A very emotional type of comment because it was so happy that, you } \\
\text { know, they kicked out that then useless government. } \\
\text { So, it's not based on looking at what he's saying, they're just lookingat }\end{array}$ \\
\hline
\end{tabular}




\begin{tabular}{|ll|} 
& this person. This person is a thief, so get, you know, don't say anything \\
& $\begin{array}{l}\text { So that is a bit unfortunate. So the comment second comment I would } \\
\text { say is this is the comments are not justified. in } \\
\text { terms of what you said, you know, it's just basically just saying what }\end{array}$ \\
\hline I feel. All I don't like this guy. So, whatever he says, I don't care what \\
hey says. I don't like this guy
\end{tabular}

Source. Interview transcripts.

As can be seen from the data, many different reasons had led to production of impolite language. The results are particularly interesting as there seems to be both negative and positive motivations to express impoliteness. Although impoliteness is generally viewed as negative and something to be avoided, the interview data revealed that an opposing point of view may exist or even negative and positive orientation co-exist in producing impoliteness.

\section{Concluding Remarks of Findings}

Evidence from the data shows 338 instances of impoliteness strategies were identified in 150 brief feedback segments, consisting of not more than 30 words. This clearly shows that feedback given tends to employ numerous impoliteness strategies simultaneously.

The most preferred strategy was the positive impoliteness strategy with the most prevailing being making the other feel uncomfortable (10.06\%), being disinterested,unconcerned and unsympathetic (9.76\%), as well as seeking disagreement (9.17\%). The second most preferred strategy was the negative impoliteness strategy with the most prevailing strategy $(30.47 \%)$ being explicitly associating the other with a negative aspect. This finding seemsto be surprising as it shows netizens resort to less direct strategies in eliciting impoliteness. According to Bousield (2008), less direct strategies do not necessarily imply less impoliteness expressed; instead the opposite may be true. Employing less direct strategies allows netizens more opportunity in constructing creative ways of using the languageto attack the hearer's face. It 
also allows the user to continue further in constructing this impoliteness rather that stopping at just a single word or phrase.

Data clearly shows netizens prefer a longwinded expression not only in the number of utterances but also in connecting the situation with various other aspects; in this sense 'more said, more satisfaction, less said, less satisfaction'. Although the Bold on-Record is known to directly threaten the hearer's face it seems to be less popular as the speaker does not get the full satisfaction of expressing his or her emotions. This scenario is clearly captured inTable 4 showing the reasons for resorting to impoliteness.

Table 4 shows that many reasons or emotions run through these netizens resulting in them producing these impolite comments. The samples provide evidence in portraying the various reasons netizens resort to impoliteness. It is quite evident that more often there seems to be not just one reason at a time but multiple reasons why netizensresort to impoliteness. Although impoliteness is often viewed as bad and something to be avoided there is also a possibility of it arising from a good or even noble reason. Oz (2017) states that people who are passionate may have a loose grip on their emotions leading to impolite communication, with incivility or abruptness. Similar views were seen in Shamilah (2015) stating that one of the factors influencing impoliteness is emotion. Shamilah elaborated that fear elicits caution in dangerous circumstances. Fear also causes people to fight for what they believe is right. Shamilah's study is supported by Culpeper's (2011) view that an individual's lack of power to control a certain situation causes fear. A similar idea on emotions relating to impoliteness was seen in Xavierine (2017) relating impolite comments to irritation and discontent. However, it must be understood that emotions interact with information (Culpeper, 2011, p. 57). These emotions are portrayed in the current study as Malaysians are enraged over the injustice inflicted upon them and fear is instilled due to the dire financial state of the country. This clearly supports Kienpointer (2008) that fear can be rational as it keeps us cautious in times of danger. Kienpointer suggested compassion as a drivingforce for altruistic behaviour, paving the way for improvement and stability.

\section{Conclusion}

Nowadays the internet is seen as a major source of information and the ability to communicate online is deemed crucial. However, with the absence of the physical face and the luxury of anonymity, online participants need not worry about offending others because they neither depend on them nor fear retaliation from them as they can remain perfectly anonymous and at the same time enjoy distant proximity (Shamilah ,2015).

Information and postings online however, have a huge impact on determining the ideas promoted in society. Furthermore, the internet connects likeminded people and provides a space for open discussion. In this situation, using impoliteness toward people out of this circle may be a method in seeking solidarity with the rest of the group. However, it may also lead to impoliteness eventually becoming the norm. Therefore, this research is intended to highlight how impoliteness is expressed and bring to light reasons that trigger impoliteness. It is hoped that with this knowledge peoplewould be more sensitive to each other, be careful with their word choices, and better understand the intention behind using impoliteness as it has the power to create chaos or to promote growth and stability in society.

\section{References}

Atyaf, H. I. (2020). A socio-inguistic analysis of impoliteness in political tweets. International Journal of Innovation Creativity and Change, 11(1) 
https://www.researchgate.net/publication/339400633

Creswell, J. W. (2014). Educational research: Planning, conducting, and evaluatingquantitative and qualitative research (4th ed.). Boston, MA: Pearson.

Culpeper, J. (2005). Impoliteness and \{Entertainment $\}$ in the $\{$ Television $\{$ Quiz $\}$ SShow $\}$ :

\{The\} \{Weakest\} \{Link\}. Journal of Politeness Research. Language, Behaviour, Culture, 1(1), 35-72. https://doi.org/10.1515/jplr.2005.1.1.35

Culpeper, J. (2011). Impoliteness: Using language to cause offence. Cambridge: Cambridge University Press.

Goffman, E. (1967). Interaction ritual: Essays on face-to-face behaviour. New York:Anchor Books.

Hu, H. C. (1944). The Chinese Concepts of "Face." American Anthropologist, 46(1), 45-64. https://doi.org/10.1377/hlthaff.6.2.57

Kasim, A., \& Sani, M. A. (2016). The 2013 general elections in Malaysia: An analysisof online news portals. Kasetsart Journal of Social Sciences, 37(2), 119-125. https://doi.org/10.1016/j.kjss.2015.05.001

Kienpointer, M. (2008) Language and Emotional Arguments. Journal of Politeness Research: Language, Behaviour, Culture, 4(2), 243-265.

Leech, G. (2007). Politeness: Is there an East-West divide? Journal of Politeness Research,3(2), 137-206. https://doi.org/10.1515/PR.2007.009

Locher, M. A. (2010). Introduction: Politeness and impoliteness in computer-mediated communication. Journal of Politeness Research, 6(1), 1-5. https://doi.org/10.1515/JPLR.2010.001

Locher, M. A., \& Bousfield, D. (2008). Introduction: Impoliteness and power in language. In D. Bousfield \& M. A. Locher (Eds.), Impoliteness in language: Studies on its interplay with power in theory and practice. Language, Power and Social Process, 21, 1-13. Berlin: Mouton de Gruyter.

Lorenzo-Dus, N., Blitvich, G-C. P., \& Bou-Franch, P. (2011). On-line polylogues and impoliteness: The case of postings sent in response to the Obama Reggaeton YouTube video. Journal of Pragmatics, 43(10), 2578-2593. https://doi.org/10.1016/j.pragma.2011.03.005

Mahrani. (2017). Impolitenss strategies used on online comments in the idntimes.compolitical website. Jurnal ESTUPRO 2(2), 1079-2502.

Malaysiakini. (2018a). Najib: Harapan's opposition-style debt talk caused markets to sink. Retrieved from https://www.malaysiakini.com/news/426506

Malaysiakini. (2018b). Millions tuned into Malaysiakini, KiniTV for GE14 results. Retrieved from https://www.malaysiakini.com/news/424750

Aziz, M. F. A. (2018). Impoliteness strategies employed by facebook users in online political discourse (Unpublished Master's Thesis, International Islamic University, Malaysia).

Akmal, N. A. Al G. (2018). Online animosity: Impoliteness strategies and triggersof hostility in a social networking site in Brunei. Southeast Asia: A Multidisciplinary Journal, 18.71-84

Oz, M., Pei, Z., \& Gina, M. C. (2017). Twitter versus Facebook: Comparing Incivilityimpoliteness and deliberative attributes.

Retrieved from https://www.researchgate.net/publication/322164248

Rabab'ah, G., \& Alali, N. (2019). Impoliteness in reader comments on the Al-Jazeera channel news website. Journal of Politeness Research Language Behaviour Culture,16(1), 1-22. https://doi.org/10.1515/pr-2017-0028 
Shamilah, A. H. (2015). Impoliteness strategies used in a politician's Facebook (Unpublished Master's thesis, University of Malaya, Kuala Lumpur). Retrieved from http://studentsrepo.um.edu.my/6002/1/THESIS_SHAMILAH_ABDUL_HALIM_TGBO 90009.pdf

Spencer-Oatey, H. (2005). Impoliteness, face and perceptions of rapport: Unpacking their bases and interrelationships. Journal of Politeness Research: Language, Behaviour and Culture, 1(1), 95-120.

Vladimirou, D., \& House, J. (2018). Ludic impoliteness and globalisation on Twitter: "I speak England very best" \#agglika_Tsipra, \#Tsipras \#Clinton. Journal of Pragmatics,134, 149162. https://doi.org/10.1016/j.pragma.2018.05.005

Xavierine, J. (2017). Impoliteness Strategies in the Social Media Comments on the Low YatPlaza Incident (Master's thesis, University of Malaya, Kuala Lumpur). Retrieved from http://studentsrepo.um.edu.my/8532/1/Low_Yat_Complete_paper.pdf

Xiangdong, L. (2017). Impoliteness in reader comments on Japanese online news sites. International Journal of Language Literature and Linguistics, 3(2).

https://www.researchgate.net/publication/318202821 